\title{
Bacteria attenuation by iron electrocoagulation governed by interactions between bacterial phosphate groups and $\mathrm{Fe}(\mathrm{III})$ precipitates
}

\author{
Caroline Delaire*,†, Case M. van Genuchten ${ }^{\S}$, Susan E. Amrose ${ }^{\dagger}$, Ashok J. Gadgil ${ }^{\dagger, *}$
}

$\dagger$ Department of Civil and Environmental Engineering, University of California, Berkeley, California 94720-1710, United States

$\S$ Department of Earth Sciences - Geochemistry, Faculty of Geosciences, Utrecht University, Utrecht 3508TA, The Netherlands

*nergy Technologies Area, Lawrence Berkeley National Laboratory, Berkeley, California 94720, United States

* Corresponding author: Department of Civil and Environmental Engineering, University of California, Berkeley, CA 94720-1710, United States. Phone: (+1) 510-417-9491; email: caroline.delaire@ orange.fr

(C) 2016. This manuscript version is made available under the Elsevier user license http://www.elsevier.com/open-access/userlicense/1.0/ 


\begin{abstract}
Iron electrocoagulation (Fe-EC) is a low-cost process in which $\mathrm{Fe}(\mathrm{II})$ generated from an $\mathrm{Fe}(0)$ anode reacts with dissolved $\mathrm{O}_{2}$ to form (1) $\mathrm{Fe}(\mathrm{III})$ precipitates with an affinity for bacterial cell walls and (2) bactericidal reactive oxidants. Previous work suggests that Fe-EC is a promising treatment option for groundwater containing arsenic and bacterial contamination. However, the mechanisms of bacteria attenuation and the impact of major groundwater ions are not well understood. In this work, using the model indicator Escherichia coli (E. coli), we show that physical removal via enmeshment in EC precipitate flocs is the primary process of bacteria attenuation in the presence of $\mathrm{HCO}_{3}{ }^{-}$, which significantly inhibits inactivation, possibly due to a reduction in the lifetime of reactive oxidants. We demonstrate that the adhesion of EC precipitates to cell walls, which results in bacteria encapsulation in flocs, is driven primarily by interactions between EC precipitates and phosphate functional groups on bacteria surfaces. In single solute electrolytes, both $\mathrm{P}(0.4 \mathrm{mM})$ and $\mathrm{Ca} / \mathrm{Mg}(1-13 \mathrm{mM})$ inhibited the adhesion of EC precipitates to bacterial cell walls, whereas $\mathrm{Si}(0.4 \mathrm{mM})$ and ionic strength $(2-200 \mathrm{mM})$ did not impact $E$. coli attenuation. Interestingly, P $(0.4 \mathrm{mM})$ did not affect $E$. coli attenuation in electrolytes containing $\mathrm{Ca} / \mathrm{Mg}$, consistent with bivalent cation bridging between bacterial phosphate groups and inorganic $\mathrm{P}$ sorbed to EC precipitates. Finally, we found that EC precipitate adhesion is largely independent of cell wall composition, consistent with comparable densities of phosphate functional groups on Gram-positive and Gram-negative cells. Our results are critical to predict the performance of Fe-EC to eliminate bacterial contaminants from waters with diverse chemical compositions.
\end{abstract}

\title{
Keywords
}

Iron electrocoagulation; bacteria attenuation; bacterial surface functional groups; specific interactions; bivalent cations; oxyanions. 


\section{Graphical abstract}

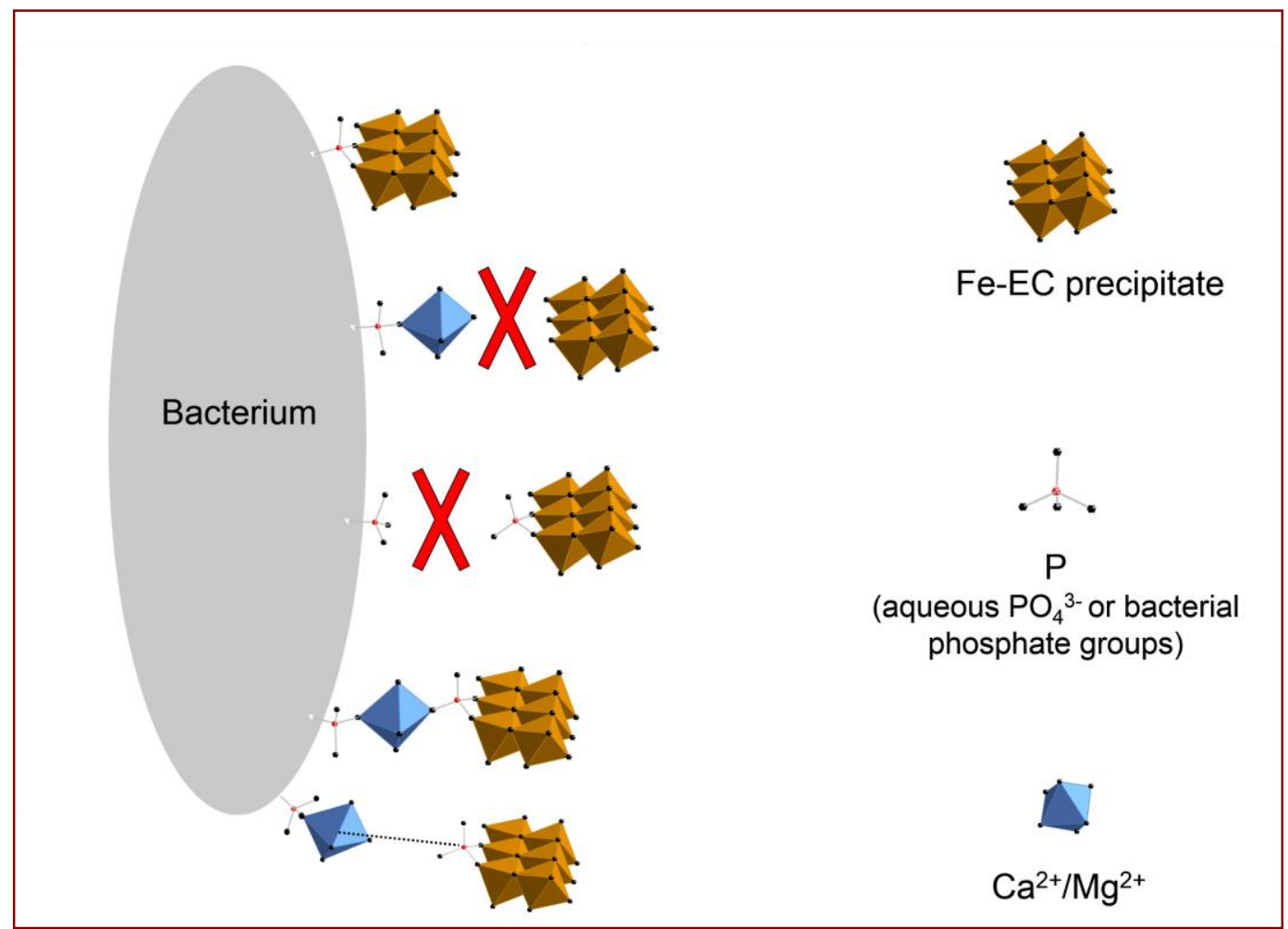

\section{Introduction}

Iron electrocoagulation $(\mathrm{Fe}-\mathrm{EC})$ is a process relying on the electrolytic dissolution of an $\mathrm{Fe}(0)$ anode to generate $\mathrm{Fe}(\mathrm{II})$, which is oxidized by dissolved $\mathrm{O}_{2}$ to produce $\mathrm{Fe}(\mathrm{III})$ (oxyhydr)oxide precipitates with an affinity for microbial and chemical contaminants (Delaire et al., 2015; Tanneru and Chellam, 2012; van Genuchten et al., 2012). Fe-EC can efficiently remove arsenic from contaminated groundwater (Amrose et al., 2014; Li et al., 2012), and has also been shown to attenuate bacteria in a range of water matrices (Barrera-Díaz et al., 2003; Delaire et al., 2015; Ghernaout et al., 2008). In a recent study, we demonstrated that Fe-EC can attenuate Escherichia coli (E. coli) from synthetic Bengal groundwater (SBGW) without detriment to arsenic removal (Delaire et al., 2015), confirming that Fe-EC has 
promising applications for low-cost groundwater remediation (Amrose et al., 2014). Two processes contributed to bacteria attenuation in Fe-EC: (1) physical removal, caused by the adhesion of EC precipitates to cell walls, resulting in bacteria enmeshment in Fe(III) flocs and subsequent settling, and (2) inactivation by reactive species produced upon $\mathrm{Fe}(\mathrm{II})$ oxidation by $\mathrm{O}_{2}$. Fundamental aspects of the mechanisms underlying these two processes remain unknown. For example, the bacterial functional groups and the type of chemical interactions (electrostatic versus specific bonding) governing bacteria enmeshment in flocs are not well understood. In addition, the effect of major groundwater components, such as $\mathrm{HCO}_{3}{ }^{-}, \mathrm{Ca}, \mathrm{Mg}, \mathrm{Si}$, and $\mathrm{P}$, which can interfere with both inactivation and removal, has not been investigated. Finally, the impact of bacteria surface structure (Gram-positive versus Gram-negative, smooth versus rough Gram-negative) on attenuation has not been elucidated. By addressing these knowledge gaps, this study can improve considerably our predictions of Fe-EC performance in various water matrices containing different types of bacterial contamination.

Four types of surface functional groups are present on bacterial cell walls at comparable densities: hydroxyl $\left(\mathrm{pK}_{\mathrm{a}} \sim 9.0\right)$, amine $\left(\mathrm{pK}_{\mathrm{a}} \sim 9.0\right)$, carboxyl $\left(\mathrm{pK}_{\mathrm{a}} \sim 4.7\right)$, and phosphate groups $\left(\mathrm{pK}_{\mathrm{a} 1} \sim 3.1, \mathrm{pK}_{\mathrm{a} 2} \sim\right.$ 6.6) (Borrok et al., 2005; Ngwenya et al., 2003). Hydroxyl and amine moieties do not have a strong affinity for Fe(III) oxides (McBride and Kung, 1991; Norén et al., 2008) and therefore they are not expected to strongly interact with EC precipitates. By contrast, carboxyl and phosphate moieties have strong affinities for Fe(III) oxides (Arai and Sparks, 2001; Chassé et al., 2015; Filius et al., 2000; van Genuchten et al., 2014a) and studies using Attenuated Total Reflectance Fourier-Transform Infrared spectroscopy (ATR-FTIR) have shown direct bonding of bacterial phosphate and carboxyl groups to hematite and goethite (Elzinga et al., 2012; Parikh and Chorover, 2006; Parikh et al., 2014). However, these studies were performed in controlled laboratory systems and simple water matrices, and they cannot be directly extrapolated to Fe-EC in groundwater, where precipitates and bacteria interact in an agitated suspension and in the presence of bivalent cations $(\mathrm{Ca}$ and $\mathrm{Mg}$ ) and oxyanions ( $\mathrm{P}$ and $\mathrm{Si}$ ), which can sorb 
to bonding sites on bacteria (Beveridge and Koval, 1981; Johnson et al., 2007) and precipitates (van Genuchten et al., 2014b), respectively, and may therefore interfere with adhesion.

In addition to electrolyte composition, a number of studies have shown that the biomolecular structure of bacterial cell walls can affect their interactions with mineral surfaces through changes in surface charge, hydrophobicity, and steric hindrance (Chen and Walker, 2012; Jacobson et al., 2015; Walker et al., 2004). Because waterborne pathogenic bacteria and indicator organisms span the range of Grampositive, smooth and rough (with and without O-antigen) Gram-negative strains (WHO, 2011), understanding the impact of cell wall structure on bacteria attenuation with $\mathrm{Fe}-\mathrm{EC}$ is essential to generalize our findings to all bacterial species relevant to water quality.

Spectroscopic techniques such as ATR-FTIR, X-ray fluorescence (XRF) and X-ray absorption spectroscopy (XAS) have been used to study bacteria-Fe systems (Chan et al., 2009; Elzinga et al., 2012; Miot et al., 2009; Yan et al., 2016). However, these techniques cannot adequately determine bacteria$\mathrm{Fe}(\mathrm{III})$ interactions in systems where Fe(III) is co-precipitated with bacteria in complex electrolytes similar to groundwater. For example, P-Fe bonds from bacteria-precipitate interactions and from aqueous P sorption to precipitates look very similar using ATR-FTIR (Elzinga et al., 2012) and would not be distinguishable with P K-edge XAS (Kelly et al., 2008). Additionally, ATR-FTIR is not suited to investigate interactions taking place inside large flocs due to the low penetration length of infrared beams in aqueous medium $(\sim 1 \mu \mathrm{m})$. To circumvent these limitations, the present study proposes an innovative approach, where macroscopic data of bacteria attenuation in systematically varied electrolytes are combined with $\zeta$-potential measurements to elucidate the molecular interactions between bacteria and EC precipitates. Although this approach can only provide indirect evidence for specific interactions between bacteria and precipitates, it builds upon previous spectroscopic studies, which have identified bacteria-Fe oxide bonding processes in simple controlled systems (Elzinga et al., 2012; Parikh and Chorover, 2006; Parikh et al., 2014) and structures of Fe-EC precipitates in complex water matrices (van Genuchten et al., 2014a, 2014b), to gain information about bacteria removal mechanisms in groundwater-like electrolytes. 
The goals of this study are to: (1) determine the impact of $\mathrm{HCO}_{3}{ }^{-}, \mathrm{Ca}, \mathrm{Mg}, \mathrm{P}$, and $\mathrm{Si}$ on bacteria attenuation with Fe-EC, (2) identify the bacterial functional groups involved in the adhesion of EC precipitates to cell walls and investigate the type of interaction (electrostatic versus specific), and (3) test the generalizability of these conclusions to various bacteria types. To achieve these objectives, we first compared $\mathrm{Fe}-\mathrm{EC}$ with $\mathrm{FeCl}_{3}$ coagulation to distinguish the contributions of inactivation and removal via enmeshment in flocs to overall bacteria attenuation in Fe-EC as a function of the $\mathrm{HCO}_{3}{ }^{-}$concentration. Inactivation results were confirmed using live-dead staining. Second, we systematically investigated the effect of ionic strength, $\mathrm{Ca} / \mathrm{Mg}$, and $\mathrm{P} / \mathrm{Si}$ on $E$. coli attenuation, both in single and multiple solute electrolytes, to constrain the bacterial functional groups involved in precipitate adhesion to cell walls. $\zeta$ potential, a proxy for surface charge, was used to assess the interaction of major groundwater ions with the surface of EC precipitates or E. coli cells. Third, we validated our proposed mechanism with 3 bacteria strains bearing different surface structures (smooth and rough Gram-negative, and Grampositive). Our results strongly suggest that Fe-EC can be used to remove various types of bacteria from a wide range of water matrices representative of regions affected by arsenic and microbial contamination of drinking water sources. More generally, this study can help predict the performance of Fe-EC, and other Fe-based coagulation processes, to reduce bacterial contaminants from drinking water and wastewater.

\section{Methods}

\subsection{Bacteria preparation and enumeration}

One Gram-positive and two Gram-negative bacterial strains were used: Enterococcus faecalis (ATCC 19433, no antibiotic resistance), Escherichia coli K12 (NCM 4236, kanamycin-resistant), and Escherichia coli ECOR 10 (from STEC center, ampicillin-resistant (Mazel et al., 2000)). K12 is a rough strain (no Oantigen) (Stevenson et al., 1994) whereas ECOR 10 is a smooth strain (O-antigen present, serotype O6) (STEC center, 2016). After three propagations in growth media amended with appropriate antibiotics, stationary-phase bacteria were rinsed 3 times and resuspended in $100 \mathrm{mM} \mathrm{NaCl}$ as detailed in the 
Supporting Information. Bacteria were spiked in Fe-EC electrolytes to achieve initial concentrations of $10^{6.1-6.7} \mathrm{CFU} / \mathrm{mL}\left(10^{5.0-5.8} \mathrm{CFU} / \mathrm{mL}\right.$ for E. faecalis). Bacteria concentrations were enumerated in duplicate in $0.1 \mathrm{~mL}$ aliquots as colony forming units $(\mathrm{CFU})$ using the spread plate technique on agar amended with appropriate antibiotics (detection limit of $10 \mathrm{CFU} / \mathrm{mL}$ ), as described in the Supporting Information.

\subsection{Electrolytes}

The list of electrolytes used in bacteria attenuation experiments is specified in Table S1. In summary, we first varied the concentration of $\mathrm{HCO}_{3}{ }^{-}(0.1-8.0 \mathrm{mM})$ to examine its impact on bacteria inactivation. Second, a range of ionic strengths was investigated by varying $\mathrm{NaCl}$ (in deionized water and in $\mathrm{SBGW}$ ) or $\mathrm{NaClO}_{4}$ (in $1 \mathrm{mM} \mathrm{CaCl}_{2}$ ). Then, concentrations of bivalent cations (Ca: 0-13.5 mM and Mg: 0-10.6 $\mathrm{mM}$ ) and oxyanions (P: 0-0.4 mM and Si: 0-0.4 mM) were systematically varied, in single and composite electrolytes, to elucidate their effect on bacteria removal. Finally, SBGW containing $8.2 \mathrm{mM} \mathrm{HCO}_{3}^{-}, 2.7$ $\mathrm{mM} \mathrm{Ca}, 2.0 \mathrm{mM} \mathrm{Mg}, 1.3 \mathrm{mM} \mathrm{Si}, 0.15 \mathrm{mM}$ P, and $6.3 \mu \mathrm{M} \mathrm{As}(\mathrm{III})$, was prepared as described elsewhere (Delaire et al., 2015) and used as the electrolyte in some experiments. All experiments were conducted at $\mathrm{pH} 7.0 \pm 0.3$, except for the comparisons between the three bacterial strains, which were conducted at $\mathrm{pH}$ $7.5 \pm 0.2$. The $\mathrm{pH}$ was held constant throughout experiments by adding $\mathrm{HCl}, \mathrm{NaOH}$ or $\mathrm{NaHCO}_{3}$ as needed. Electrolytes were selected in part to overlap with previous work on the structure of EC precipitates (van Genuchten et al., 2014a, 2014b, 2012), which we leverage in our interpretations of bacteria attenuation and $\zeta$-potential measurements.

\subsection{Fe-EC and $\mathrm{FeCl}_{3}$ experiments}

The procedure used for Fe-EC experiments has been described elsewhere (Delaire et al., 2015) and is detailed in the Supporting Information. Briefly, two $1 \mathrm{~cm} \times 8 \mathrm{~cm} \mathrm{Fe}(0)$ electrodes were submerged in 200 $\mathrm{mL}$ of electrolyte spiked with bacteria (anodic submerged area of $3 \mathrm{~cm}^{2}$ ). In all experiments, a current 
density of $10 \mathrm{~mA} / \mathrm{cm}^{2}$ was applied for $11 \mathrm{~min}$, resulting in a Faradaic Fe dosage of $0.5 \mathrm{mM}$, which was chosen to result in a range of detectable post-treatment E. coli concentrations. After the electrolysis stage, suspensions were stirred open to the atmosphere for 90-180 min to allow for complete Fe(II) oxidation and formation of $\mathrm{Fe}(\mathrm{III})$ precipitates. Suspensions were then left to settle overnight to separate individual cells from cells associated with EC precipitates. When required for floc formation and settling (Table S1), $5 \mathrm{mg} / \mathrm{L}-\mathrm{Al}$ of $\mathrm{Al}_{2}\left(\mathrm{SO}_{4}\right)_{3}$ (alum) was added at the end of the mixing period, along with approximately 1.5 $\mathrm{mM} \mathrm{NaHCO} 3$ to avoid a $\mathrm{pH}$ drop. Preliminary tests confirmed that the addition of alum did not significantly modify bacteria attenuation (see Supporting Information). Solution $\mathrm{pH}$ was not controlled during the settling stage. In a subset of experiments, coagulation by $\mathrm{FeCl}_{3}$ addition was used instead of Fe-EC to isolate the contribution of removal from that of inactivation. In these experiments, $1 \mathrm{~mL}$ of a $100 \mathrm{mM} \mathrm{FeCl} 3$ solution was added to the electrolyte and the solution $\mathrm{pH}$, which dropped to $\sim 3$ during $\mathrm{FeCl}_{3}$ addition, was re-adjusted to $7.0 \pm 0.1$ in less than $5 \mathrm{~min}$.

Unfiltered and filtered ( $0.45 \mu \mathrm{m}$ nylon filters) samples were taken before Fe-EC, and before and after overnight settling, for measurements of $\mathrm{Fe}, \mathrm{As}, \mathrm{Ca}, \mathrm{Mg}, \mathrm{P}$, and $\mathrm{Si}$ by inductively coupled plasma optical emission spectrometry (ICP-OES, PerkinElmer 5300 DV, measurement error typically < 5\%). All samples for ICP-OES analysis were digested in $0.2 \mathrm{M} \mathrm{HCl}$. Filtered and unfiltered samples were used to measure $\mathrm{Fe}(\mathrm{II})$ and total $\mathrm{Fe}(\mathrm{Fe}(\mathrm{II})+\mathrm{Fe}(\mathrm{III}))$, respectively (Delaire et al., 2015). Across the 113 bacteria attenuation experiments reported here, the total Fe concentration after Fe-EC (Fe dosage) was 96\% $\pm 7 \%$ of the value predicted by Faraday's law (0.5 mM). Unoxidized Fe(II) (before settling) and unsettled Fe (after settling) were $<1.2 \%$ and $<4.7 \%$ of the total Fe dosed, respectively. Because the formation of calcite, magnesite, or hydroxyapatite in our experiments was limited if not negligible (see Supporting Information), $\mathrm{Ca} / \mathrm{Mg} / \mathrm{P}$ removal measured by $\mathrm{ICP}-\mathrm{OES}$ was used as a proxy for $\mathrm{Ca} / \mathrm{Mg} / \mathrm{P}$ uptake by $\mathrm{EC}$ precipitates. Bacteria attenuation was calculated as the difference between log CFU concentrations before Fe-EC and after settling (samples taken from the supernatant, $\sim 3 \mathrm{~cm}$ below the surface), and therefore accounts for both inactivation and removal via enmeshment in flocs. Bacteria attenuation experiments 
were generally replicated three or more times, except for 12 experiments conducted in duplicate or less (see Table S2). We report average bacteria attenuations \pm one standard deviation across replicates.

Finally, to assess the effect of P/Si on the uptake of carboxyl moieties by EC precipitates, we performed citrate removal experiments using Fe-EC in the presence and absence of oxyanions under conditions identical to E. coli removal experiments, using $10 \mathrm{mg} / \mathrm{L}-\mathrm{Al}$ of alum before settling (Table S1). Citrate concentrations were measured as total $\mathrm{C}$ with a TOC-V $\mathrm{VSH}_{\mathrm{CH}}$ analyzer (Shimadzu).

\section{4. $\zeta$-potential measurements and bacterial viability tests}

In this study, $\zeta$-potential measurements, which are a proxy for surface charge, were used to track the impact of major groundwater ions on the surface of EC precipitates or E. coli K12 cells. $\zeta$-potential was measured by dynamic light scattering (Malvern Zetasizer Nano-ZS) at $633 \mathrm{~nm}$. In addition, qualitative assessments of membrane permeabilization, which were used as a proxy for bacteria inactivation, were performed with the BacLight LIVE-DEAD kit (Invitrogen) used in conjunction with fluorescent microscopy (Zeiss AxioImager, 63× Plan-Apochromat objective, EndoGFP and mCherry filters, UC Berkeley CNR Biological Imaging Facility). Sample preparation and data collection procedures are described in the Supporting Information.

\subsection{Model of $\mathrm{Ca} / \mathrm{Mg}$ complexation by bacterial cell walls}

Drawing on previous work (Johnson et al., 2007; Ngwenya et al., 2003), we derived a simple equilibrium surface complexation model, which included three bivalent cation adsorption sites on bacterial cell walls: carboxyl groups, protonated and deprotonated phosphate groups. The model predicts the percentage of bacterial phosphate and carboxyl groups complexed by $\mathrm{Ca}$ and $\mathrm{Mg}$ as:

$\%_{P}$ groups complexed $=\frac{K_{P 1, C a}\left[\mathrm{Ca}^{2+}\right]+K_{P 1, M g}\left[\mathrm{Mg}^{2+}\right]+\frac{K_{A 2}}{\left[\mathrm{H}^{+}\right]}\left(K_{P 2, \mathrm{Ca}}\left[\mathrm{Ca}^{2+}\right]+K_{P 2, \mathrm{Mg}}\left[\mathrm{Mg}^{2+}\right]\right)}{\frac{\left[\mathrm{H}^{+}\right]}{K_{A 1}}+1+\frac{K_{A 2}}{\left[\mathrm{H}^{+}\right]}+K_{P 1, C a}\left[\mathrm{Ca}^{2+}\right]+K_{P 1, M g}\left[\mathrm{Mg} g^{2+}\right]+\frac{K_{A 2}}{\left[H^{+}\right]}\left(K_{P 2, C a}\left[\mathrm{Ca}^{2+}\right]+K_{P 2, M g}\left[\mathrm{Mg}^{2+}\right]\right)} * 100$ 
$\%_{C}$ groups complexed $=\frac{K_{C, C a}\left[\mathrm{Ca}^{2+}\right]+K_{C, M g}\left[\mathrm{Mg}^{2+}\right]}{\frac{\left[\mathrm{H}^{+}\right]}{K_{A}}+1+K_{C, C a}\left[\mathrm{Ca}^{2+}\right]+K_{C, M g}\left[\mathrm{Mg}^{2+}\right]} * 100$

Deprotonation constants of bacterial surface functional groups and $\mathrm{Ca}$ adsorption constants were obtained directly from the literature (Johnson et al., 2007). Mg adsorption constants were derived from a relationship between metal-acetate and metal-bacteria complexation constants proposed by Johnson et al (Johnson et al., 2007). Additional details regarding the derivation of this model, including equilibrium constants, are given in the Supporting Information and Table S3.

\section{Results and Discussion}

\subsection{Effect of $\mathrm{HCO}_{3}{ }^{-}$on the contributions of removal and inactivation}

The effect of $8 \mathrm{mM} \mathrm{HCO}_{3}{ }^{-}$on $E$. coli attenuation by $\mathrm{Fe}-\mathrm{EC}$ and $\mathrm{FeCl}_{3}$ coagulation is shown in Figure 1a. Representative images of live-dead stained E. coli are presented in Figure 1b-e. Whereas $8 \mathrm{mM}$ $\mathrm{HCO}_{3}{ }^{-}$did not significantly affect $E$. coli attenuation by coagulation with $\mathrm{FeCl}_{3}$, the presence of $\mathrm{HCO}_{3}{ }^{-}$ decreased attenuation by Fe-EC by $\sim 1.2 \mathrm{log}$. Because no Fenton-type reactive oxidants are produced from an $\mathrm{Fe}$ (III) salt -due to the absence of Fe(II) - (Hug and Leupin, 2003), minimal inactivation occurs during $\mathrm{FeCl}_{3}$ coagulation (consistent with live-dead staining, Figure $1 \mathrm{~b}-\mathrm{c}$ ), which implies that attenuation via $\mathrm{FeCl}_{3}$ addition is exclusively due to physical removal (enmeshment in flocs). In addition, Fe-EC and $\mathrm{FeCl}_{3}$ coagulation generate precipitates with virtually identical structures and surface properties (Li et al., 2014; Roberts et al., 2004; van Genuchten et al., 2012). Therefore, $\mathrm{FeCl}_{3}$ coagulation can be used as a proxy for bacteria removal in Fe-EC. Consequently, the difference in attenuations between Fe-EC and $\mathrm{FeCl}_{3}$ coagulation can be attributed to inactivation.

As shown in Figure 1a, $\mathrm{HCO}_{3}{ }^{-}$did not affect physical removal, which is consistent with $\zeta$-potential measurements showing that $\mathrm{HCO}_{3}{ }^{-}$does not significantly interact with the surface of E. coli cells or $\mathrm{Fe}(\mathrm{III})$ precipitates (Figure S1). By contrast, $8 \mathrm{mM} \mathrm{HCO}_{3}{ }^{-}$decreased inactivation substantially by $\sim 1.2 \log$ (Figure 1a), consistent with significantly lower membrane permeabilization (Figure 1d-e). Therefore, 
because inactivation is likely to be a marginal attenuation process in carbonated waters, we do not focus on a deep investigation of inactivation mechanisms in this work. However, we speculate that membrane damage may be caused by reactive intermediates such as $\mathrm{O}_{2}{ }^{\bullet-}, \mathrm{H}_{2} \mathrm{O}_{2}$, and $\mathrm{Fe}(\mathrm{IV})$, which are generated during Fenton-type reactions (Hug and Leupin, 2003; Keenan and Sedlak, 2008) and have been associated with bactericidal effects (Alt et al., 1999; Ikawa et al., 2010; Kim et al., 2010). The $\mathrm{CO}_{3}{ }^{\bullet}$ - radical, which is produced when $\mathrm{HCO}_{3}{ }^{-}$or $\mathrm{Fe}$ (II)-carbonate complexes react with $\mathrm{H}_{2} \mathrm{O}_{2}$ (Hug and Leupin, 2003; Medinas et al., 2007)is much more reactive and therefore shorter-lived than $\mathrm{O}_{2}{ }^{\bullet}, \mathrm{H}_{2} \mathrm{O}_{2}$, and $\mathrm{Fe}(\mathrm{IV}$ ) (Augusto and Miyamoto, 2011; Jacobsen et al., 1998; Neta et al., 1988) (see Supporting Information).Thus, the inhibition of inactivation by $\mathrm{HCO}_{3}{ }^{-}$might be explained by a shift in the nature of reactive species produced during Fe-EC towards a shorter-lived oxidant $\left(\mathrm{CO}_{3}{ }^{\bullet-}\right)$ that is more likely to die off in the bulk than to interact with cell membranes.

Overall, Figure 1 shows that both inactivation and removal (via enmeshment in flocs) contribute to E. coli attenuation in $\mathrm{Fe}-\mathrm{EC}$, and that the concentration of $\mathrm{HCO}_{3}{ }^{-}$governs the amount of inactivation. In the remaining sections of our study, we will focus on removal. Interactions between EC precipitates and E. coli cells are investigated by varying levels of ionic strength, $\mathrm{Ca}, \mathrm{Mg}, \mathrm{P}$, and $\mathrm{Si}$. Because these ions are not expected to react with oxidants such as $\mathrm{O}_{2}{ }^{\bullet-}, \mathrm{H}_{2} \mathrm{O}_{2}$, or Fe(IV) (Hug and Leupin, 2003; Li et al., 2012; Roberts et al., 2004), nor to interact with lipid aliphatic chains, which are the target of oxidants on cell membranes (lipid peroxidation), they are assumed to have a negligible effect on inactivation. Therefore, their potential impact on $E$. coli attenuation will be solely attributed to changes in removal.

\subsection{Effect of ionic strength}

Increasing ionic strength over 2 orders of magnitude $(2-200 \mathrm{mM})$, which results in increased charge screening (Debye length decreased tenfold), did not significantly affect E. coli attenuation by Fe-EC, regardless of the initial electrolyte composition (Figure S2). The negligible effect of ionic strength suggests that electrostatic interactions play a secondary role compared to specific interactions in the adhesion of EC precipitates to E. coli cells. In the following two sections, we investigate the bacterial 
surface sites involved in these interactions by systematically varying the concentration of bivalent cations and oxyanions in order to selectively complex adsorption sites on the surface of $E$. coli cells and EC precipitates, respectively.

\subsection{Effect of bivalent cations: $\mathrm{Ca}$ and $\mathrm{Mg}$}

\subsubsection{Single solute electrolytes (no oxyanions, no $\mathrm{HCO}_{3}^{-}$)}

E. coli attenuation as a function of $\mathrm{Ca}$ and $\mathrm{Mg}$ concentrations is shown in Figure $2 \mathrm{a}$. $\mathrm{Ca}$ and $\mathrm{Mg}$ both decreased E. coli attenuation, with a larger inhibitory effect observed for $\mathrm{Mg}$ (2.1 log decrease in attenuation when $\mathrm{Mg}$ increased from 0 to $10.6 \mathrm{mM})$ than for $\mathrm{Ca}(1.3 \log$ decrease in attenuation when $\mathrm{Ca}$ increased from 0 to $12.9 \mathrm{mM}$ ). Because bivalent cations should not affect inactivation (see 3.1.), these reductions in bacteria attenuation can be interpreted as reductions in E. coli removal.

Figure $2 \mathrm{~b}$ shows the $\zeta$-potential of EC precipitates and $E$. coli cells as a function of $\mathrm{Ca} / \mathrm{Mg}$ concentrations. In this single $\mathrm{Ca} / \mathrm{Mg}$ solute electrolyte, $\mathrm{EC}$ precipitates were positively charged. Increasing concentrations of $\mathrm{Ca} / \mathrm{Mg}$ had a limited effect on the $\zeta$-potential of precipitates, suggesting that bivalent cations interacted minimally with their surface, consistent with unchanged settling velocity at higher $\mathrm{Ca} / \mathrm{Mg}$ concentrations. This result was expected given the repulsive electrostatic forces between bivalent cations and positively-charged EC precipitates, and is consistent with previous work showing negligible uptake of $\mathrm{Ca} / \mathrm{Mg}$ by $\mathrm{Fe}(\mathrm{III})$ (oxyhydr)oxides at circumneutral $\mathrm{pH}$ in the absence of oxyanions (Kanematsu et al., 2013; Stachowicz et al., 2008). By contrast, Ca and Mg caused a significant increase in the $\zeta$-potential of $E$. coli cells, indicating a strong interaction between bivalent cations and bacteria surfaces. Figure $\mathrm{S} 3$ shows the percentage of bacterial functional groups complexed by bivalent cations, as predicted by our equilibrium surface model. According to this model, raising $\mathrm{Ca} / \mathrm{Mg}$ concentrations from 0 to $13 \mathrm{mM}$ leads to a significant increase in the complexation of carboxyl (from 0 to $70-80 \%$ ) and phosphate (from 0 to $90-95 \%$ ) groups, which is consistent with the observed increase in E. coli $\zeta$-potential (Figure 2b). 
Figure 2c combines E. coli attenuation results (Figure 2a) and model outputs (Figure S3) to highlight that $E$. coli removal decreases as the percentage of complexed bacterial carboxyl and phosphate groups increases. Stronger inhibition of E. coli removal by $\mathrm{Mg}$ than by $\mathrm{Ca}$ (Figure 2a) is consistent with this trend, because $\mathrm{Mg}$ has a higher affinity for bacterial surface functional groups (Beveridge and Koval, 1981) (Table S3 and Figure S3).

\subsubsection{Groundwater-like electrolytes (with oxyanions and $\mathrm{HCO}_{3}^{-}$)}

Figure $2 \mathrm{~d}$ shows the effect of $\mathrm{Ca}(0-13.5 \mathrm{mM})$ and $\mathrm{Mg}(2.4-10.5 \mathrm{mM})$ on E. coli attenuation in a groundwater-like electrolyte containing $8 \mathrm{mM} \mathrm{HCO}_{3}{ }^{-}, 1.2 \mathrm{mM} \mathrm{Si}$, and $0.4 \mathrm{mM} \mathrm{P}$. Similar to the single $\mathrm{Ca} / \mathrm{Mg}$ solute system, bivalent cations reduced E. coli attenuation, with $\mathrm{Ca} / \mathrm{Mg}$ concentrations above 10 $\mathrm{mM}$ leading to a 1-2 log decrease in attenuation.

Figure 2e shows $\zeta$-potentials of EC precipitates and E. coli cells as a function of $\mathrm{Ca} / \mathrm{Mg}$ concentrations in the groundwater-like electrolyte. Bivalent cations increased the $\zeta$-potential of $E$. coli cells, consistent with the complexation of phosphate and carboxyl groups on cell walls, as explained in section 3.3.1. In this electrolyte, EC precipitates were negatively-charged due to the sorption of $\mathrm{P}$ and, to a lesser extent, $\mathrm{Si}$ (P:Fe and Si:Fe molar solids ratios of $0.7 \pm 0.1$ and $0.06 \pm 0.04$, respectively) (Appenzeller et al., 2002; Hamid et al., 2011). In contrast to previous experiments in the absence of oxyanions, bivalent cations significantly interacted with the surface of EC precipitates in the groundwater-like electrolyte, as indicated by a substantially higher $\zeta$-potential at larger $\mathrm{Ca} / \mathrm{Mg}$ concentrations. This increase in precipitate surface charge coincided with increased $\mathrm{Ca} / \mathrm{Mg}$ uptake, with solids ratios going from $0.5 \pm 0.1$ to $1.2 \pm 0.7 \mathrm{~mol} \mathrm{Ca}$ :mol Fe, and from $0.3 \pm 0.1$ to $0.5 \pm 0.4 \mathrm{~mol} \mathrm{Mg}$ :mol $\mathrm{Fe}$, respectively. EC precipitates with similar chemical compositions (i.e. $\mathrm{Ca} / \mathrm{Mg}: \mathrm{P}: \mathrm{Fe}$ molar ratios) have been documented in previous studies performed in nearly identical electrolytes, but in the absence of bacteria (van Genuchten et al., 2014a, 2014b). In these studies, Ca was shown to interact with P sorbed to $\mathrm{Fe}(\mathrm{III})$ precipitates, via direct Ca-O-P bonds, and to a lesser extent, electrostatically. In the present study, 
the observed increase in precipitate $\zeta$-potential with $\mathrm{Ca} / \mathrm{Mg}$ in the groundwater-like electrolyte is consistent with such interactions of $\mathrm{Ca} / \mathrm{Mg}$ with $\mathrm{P}$ sorbed to $\mathrm{EC}$ precipitates.

Figure $2 \mathrm{f}$ illustrates the inverse relationship between $E$. coli attenuation in the groundwater-like electrolyte and the percentage of bacterial functional groups complexed by $\mathrm{Ca} / \mathrm{Mg}$ (derived from our model). Figure $2 \mathrm{f}$ also includes data from our previous study of E. coli attenuation in SBGW containing 2.6 mM Ca and 1.9 mM Mg (Delaire et al., 2015), which are consistent with this trend. Finally, we note that E. coli attenuations in groundwater-like electrolytes (Figure $2 \mathrm{f}$ ) were overall $\sim 1$ log lower than in single solute systems (Figure 2c), which is consistent with the inhibition of inactivation by $8 \mathrm{mM} \mathrm{HCO}_{3}{ }^{-}$ shown in section 3.1 .

Taken together, Figures $2 \mathrm{a}-\mathrm{f}$ show that $\mathrm{Ca} / \mathrm{Mg}$ decreases $E$. coli removal independent of the electrolyte, and more specifically, independent of the surface charge of EC precipitates: whether $\mathrm{Ca} / \mathrm{Mg}$ increase (Figure 2b, no oxyanions) or decrease (Figure 2e, oxyanions present) the electrostatic barrier to precipitate adhesion on cell walls, bivalent cations equally inhibit $E$. coli removal. Combined with the limited impact of ionic strength (Section 3.2 and Figure S2), this result confirms the minimal role of electrostatic interactions on $E$. coli removal and instead points to the importance of specific interactions between EC precipitates and bacterial phosphate and/or carboxyl groups. These findings are in good agreement with previous ATR-FTIR studies that provided evidence for direct bonding between Fe oxides and bacterial phosphate/carboxyl groups in more simple and controlled systems (Elzinga et al., 2012; Parikh and Chorover, 2006; Parikh et al., 2014).

\subsection{Effect of oxyanions: $P$ and $\mathrm{Si}$}

\subsubsection{Single solute electrolytes (no bivalent cations, no $\mathrm{HCO}_{3}^{-}$)}

Figure 3 a shows the effect of $0.4 \mathrm{mM} \mathrm{Si} / \mathrm{P}$ on $E$. coli attenuation in electrolytes containing no $\mathrm{Ca} / \mathrm{Mg}$. Whereas Si had no detectable effect, P reduced E. coli attenuation by $1.6 \log$. Because Si and P should not 
affect inactivation, as explained in section 3.1, these effects correspond to changes in removal via enmeshment in flocs. $\zeta$-potential measurements of EC precipitates and E. coli cells as a function of P/Si concentrations are presented in Figure $3 \mathrm{~b}$. Si and $\mathrm{P}$ had no detectable effect on the $\zeta$-potential of $E$. coli cells, reflecting the absence of interaction between these oxyanions and bacterial cell walls. By contrast, Si and P significantly decreased the $\zeta$-potential of EC precipitates, indicating oxyanion sorption (Appenzeller et al., 2002; Hamid et al., 2011), which is supported by the uptake of Si and P measured by ICP-OES (Si:Fe and P:Fe molar solids ratios of 0.3 and 0.6, respectively). Because electrostatic interactions do not play a major role in E. coli removal, as demonstrated above, lower bacteria removal in the presence of $\mathrm{P}$ cannot be explained by the decrease in precipitate surface charge. Rather, the results in Figure $3 \mathrm{a}$ indicate that inorganic aqueous $\mathrm{P}$ competes with bacterial functional groups involved in bonding to EC precipitates. By contrast, our results indicate that Si does not strongly compete with these functional groups.

Because aqueous $\mathrm{P}$ and bacterial phosphate groups are structurally and chemically similar, they are expected to compete for precipitate surfaces. However, the competition between $\mathrm{P}$ and carboxyl groups is less straight-forward. To assess the effect of $\mathrm{P}$ on the adsorption of carboxyl moieties, we measured the removal of citrate (a proxy for carboxyl groups) by Fe-EC in the presence and absence of $\mathrm{P}$. As shown in Figure 3c, $\mathrm{P}$ decreased citrate removal by nearly $54 \%$ (initial P:C molar ratio of 0.9 ). In E. coli attenuation experiments, the molar ratio of aqueous $\mathrm{P}$ to bacterial surface carboxyl groups is $\sim 2500 \mathrm{~mol} \mathrm{P}: \mathrm{mol} \mathrm{C}$ (see Supporting Information). Therefore, aqueous $\mathrm{P}$ is expected to strongly compete with bacterial carboxyl groups in attenuation experiments.

Fe(III) (oxyhydr)oxides have a much higher affinity for P than for Si (Li et al., 2014; Roberts et al., 2004). Therefore, Si is not expected to effectively compete with bacterial phosphate groups for precipitate surfaces. In contrast, Figure 3c shows that Si decreased citrate removal in Fe-EC by nearly 20\% (initial Si:C molar ratio of 0.7). In E. coli attenuation experiments, where the molar ratio of Si to bacterial surface carboxyl groups is orders of magnitude higher ( 2500, see Supporting Information), it is thus likely that 
Si would inhibit bacteria removal if carboxyl groups played an important role in the adhesion of EC precipitates. Because Si had no detectable effect on E. coli attenuation (Figure 3a), we propose that phosphate groups are the primary sites for the adhesion of EC precipitates to cell walls, with negligible contributions from carboxyl groups.

\subsubsection{Groundwater-like electrolytes (with bivalent cations, $\mathrm{HCO}_{3}{ }^{-}$and $\mathrm{Si}$ )}

In Figure 3d, we show the effect of $\mathrm{P}(0-0.4 \mathrm{mM})$ on E. coli attenuation in the presence of $\mathrm{Ca}$ ( 2 and 9 $\mathrm{mM})$ or $\mathrm{Mg}(8 \mathrm{mM})$ in a groundwater-like electrolyte containing $8 \mathrm{mM} \mathrm{HCO}_{3}{ }^{-}$and $1.2 \mathrm{mM} \mathrm{Si}$. In contrast to experiments in electrolytes free of bivalent cations, where P decreased E. coli removal by $1.6 \log$ (Figure 3a), $0.4 \mathrm{mM} \mathrm{P}$ had no effect on $E$. coli removal in the presence of $\mathrm{Ca} / \mathrm{Mg}$. We note that lower $E$. coli attenuations in Figure 3d compared to Figure 3a $(\sim-2 \log )$ are due to the inhibition of inactivation by $8 \mathrm{mM} \mathrm{HCO}_{3}{ }^{-}$(shown in section 3.1) and to the reduction in removal caused by $\mathrm{Ca} / \mathrm{Mg}$ (shown in section 3.3).

Figures 3e-f show $\zeta$-potential measurements of EC precipitates and E. coli cells, respectively, as a function of $\mathrm{P}$ concentration in the groundwater-like electrolyte containing bivalent cations. Figure $3 \mathrm{e}$ shows that $\mathrm{P}$ did not interact significantly with bacterial cells, as expected. In contrast to single oxyanion systems (Figure 3b), EC precipitates in the groundwater-like electrolyte were negatively-charged for all P concentrations, due to sorbed $\mathrm{Si} / \mathrm{P}$. In addition, the $\zeta$-potential of EC precipitates did not decrease when the $\mathrm{P}$ concentration increased from 0 to $0.4 \mathrm{mM}$, despite substantial P uptake by precipitates (P:Fe molar solids ratios of 0.6-0.8, see Table S4). This result stands in strong contrast with electrolytes containing no $\mathrm{Ca} / \mathrm{Mg}$, where high concentrations of $\mathrm{P}(0.4 \mathrm{mM})$ and similar $\mathrm{P}: \mathrm{Fe}$ solids ratios $(0.6 \mathrm{~mol}: \mathrm{mol})$ significantly decreased EC precipitate surface charge (Figure 3b). In the groundwater-like electrolytes, ICP-OES measurements indicated that $\mathrm{Ca} / \mathrm{Mg}$ uptake by EC precipitates increased by $20-200 \%$ depending on the initial $\mathrm{Ca} / \mathrm{Mg}$ concentration- in the presence of $0.4 \mathrm{mM} \mathrm{P}$ (Table S4). This co-sorption of $\mathrm{Ca} / \mathrm{Mg}$ explains the negligible impact of $\mathrm{P}$ sorption on the surface charge of EC precipitates. 
Based on the co-sorption of $\mathrm{Ca} / \mathrm{Mg}$ and $\mathrm{P}$, the behavior of precipitate and bacteria surfaces, and the negligible effect of $\mathrm{P}$ on $E$. coli removal observed in our system, we propose that $\mathrm{Ca} / \mathrm{Mg}$ can act as a bivalent cation bridge between bacterial phosphate groups and P sorbed to EC precipitates. Specifically, we propose that $\mathrm{Ca}-\mathrm{P}-\mathrm{Fe}$ or $\mathrm{Mg}-\mathrm{P}-\mathrm{Fe}$ complexes, which are consistent with $\mathrm{Ca}-\mathrm{P}-\mathrm{Fe}$ configurations previously documented in comparable electrolytes in the absence of bacteria (Senn et al., 2015; van Genuchten et al., 2014a; Voegelin et al., 2010), create additional sites at the precipitate surface that can interact with bacterial cell walls.

\subsection{Attenuation of different types of bacteria}

The attenuation of E. coli K12, E. coli ECOR 10, and E. faecalis in SBGW with an Fe dosage of 0.5 $\mathrm{mM}$ is shown in Figure 4. No significant difference between the log attenuations of the three different bacterial strains was observed, despite their considerably different cell wall structures. For example, the surface of Gram-positive E. faecalis is composed of a peptidoglycan layer topped with techoic acids, whereas the surface of Gram-negative E. coli is made of phospholipids and lipopolysaccharides (LPS) (Madigan et al., 2000). Furthermore, the two E. coli strains differ by the length of their LPS: ECOR 10 is a smooth strain with a full-length LPS (with O-antigen), whereas K12 is a rough strain with a truncated LPS (no O-antigen). Such differences in cell wall composition lead to differences in hydrophobicity, surface charge, surface roughness, and steric hindrance to approach mineral surfaces and nanoparticles (Chen and Walker, 2012; Jacobson et al., 2015; Walker et al., 2004).

Previous studies have found that cell wall composition and LPS length affect the interactions of bacteria with mineral surfaces (sand, iron-oxide coated sand, and gold nanoparticles) in systems governed by non-specific interactions, such as electrostatic, steric, hydrophobic, and van der Waals forces (Chen and Walker, 2012; Jacobson et al., 2015; Mohanty et al., 2013; Truesdail et al., 1998; Walker et al., 2004). In contrast to these studies, similar attenuation of E. coli K12, E. coli ECOR 10, and E. faecalis in our system is likely due to the dominant role of specific interactions in bacteria-precipitate adhesion. The 
literature shows that all bacterial cell walls are very similar in terms of functional groups (Borrok et al., 2005 and references therein). Specifically, phosphate functional groups, which we found to be the primary binding sites for EC precipitates on E. coli, are present in comparable abundance on Gramnegative and Gram-positive bacteria (Borrok et al., 2005) (mainly on phospholipids and on techoic acids, respectively), which is consistent with similar removal of E. coli and E. faecalis. In addition, negligible steric hindrance from longer LPS on E. coli is likely due to the small size of EC precipitates compared to bacterial cells (Figure S4).

These results suggest that Fe-EC would be similarly effective for all waterborne pathogenic bacteria, both Gram-negative (e.g. Vibrio cholera, Shigella, Salmonella, pathogenic E. coli) and Gram-positive

(e.g. E. faecalis, Bacillus cereus, Staphylococcus aureus). Finally, similar attenuation of E. coli K12 and E. coli ECOR 10 suggests that fecal pathogens, which are typically smooth strains (Felix and Pitt, 1935), would be as effectively removed as our model indicator $E$. coli K12. Overall, these results are promising for the application of Fe-EC to drinking water or wastewater treatment.

\section{Conclusions}

In this study, we showed that bacteria inactivation, which can be significant in the absence of oxidant scavengers, is largely suppressed by $\mathrm{HCO}_{3}{ }^{-}$concentrations characteristic of natural waters. Therefore, we expect physical removal to be the primary process of bacteria attenuation in most water treatment applications.

We have shown that removal is driven by the interactions of EC precipitates with bacterial phosphate groups, which may bind to $\mathrm{Fe}(\mathrm{III})$ surfaces directly or via a $\mathrm{Ca} / \mathrm{Mg}$ bridge to $\mathrm{P}$ sorbed on precipitates. These mechanisms are consistent with the minimal impact of ionic strength, which is not expected to affect significantly such specific interactions (Sposito, 2008). In light of these mechanisms, the contrasted effects of P and Si observed in this study can be generalized to other strongly- (e.g., arsenate) and weakly- 
(e.g., borate, arsenite, nitrate) sorbing oxyanions, respectively. Similarly, the observed impact of $\mathrm{Ca} / \mathrm{Mg}$ (hardness) can be extrapolated to metallic bivalent cations that may be present in wastewater, such as $\mathrm{Cu}^{2+}, \mathrm{Cd}^{2+}, \mathrm{Pb}^{2+}$, and $\mathrm{Zn}^{2+}$. Natural organic matter (NOM) has been found to inhibit virus attenuation by Fe-EC (Tanneru and Chellam, 2012). However, because NOM mainly bears carboxyl and hydroxyl moieties (Chen et al., 2002; Driver and Perdue, 2014), which have a lower sorption affinity for Fe(III) (oxyhydr)oxides than bacterial phosphate groups, it is not expected to inhibit bacteria removal by Fe-EC

significantly, consistent with our previous finding in synthetic Bengal groundwater (Delaire et al., 2015). Finally, extracellular polymeric substances (EPS), in which environmental bacteria are typically embedded, are not expected to affect the adhesion of EC precipitates significantly, because EPS contain phosphate functional groups that can form bonds with Fe(III) oxides (Omoike et al., 2004), similar to bacterial cell walls.

Consistent with the universal presence of phosphate groups on bacteria surfaces, Fe-EC is equally effective towards Gram-positive and Gram-negative bacteria, rough and smooth alike. Our results strongly suggest that Fe-EC, which is a technology applicable to decentralized arsenic remediation in low-resource settings (Amrose et al., 2014; Holt et al., 2005), can also effectively remove all types of bacterial contamination from a wide range of groundwater sources. Field validation of these promising results as well as an investigation of virus attenuation are needed to confirm the potential of Fe-EC to substitute for existing disinfection methods when applied to groundwater treatment.

\section{Acknowledgements}

This work was supported by the Development Impact Lab (USAID Cooperative Agreement AID-OAAA-13-00002) and the Andrew and Virginia Rudd Family Foundation Chair for Safe Water and Sanitation administered by the Blum Center for Developing Economies. Additionally, C.M.v.G. acknowledges funding support from the Netherlands Organization for Scientific Research (NWO) through a Veni grant. 
We wish to express our gratitude to Kara Nelson, who provided useful discussions regarding the complexation of $\mathrm{Ca} / \mathrm{Mg}$ to bacterial functional groups, and to David Sedlak, Denise Schichnes, John Wertz, and Aidan Cecchetti for their kind assistance along various steps of this work. $\zeta$-potential measurements were conducted at the Molecular Foundry of Lawrence Berkeley National Laboratory and supported by the Office of Science, Office of Basic Energy Sciences, of the U.S. Department of Energy under Contract No. DE-AC02-05CH11231.

\section{Supporting Information}

The Supporting Information provides detailed descriptions of experimental protocols (for Fe-EC experiments, $\zeta$-potential measurements, and fluorescent microscopy), the bacteria surface complexation model, and the reactivity of strong oxidants produced in Fe-EC. Supporting figures and tables referenced in the text are also included. 


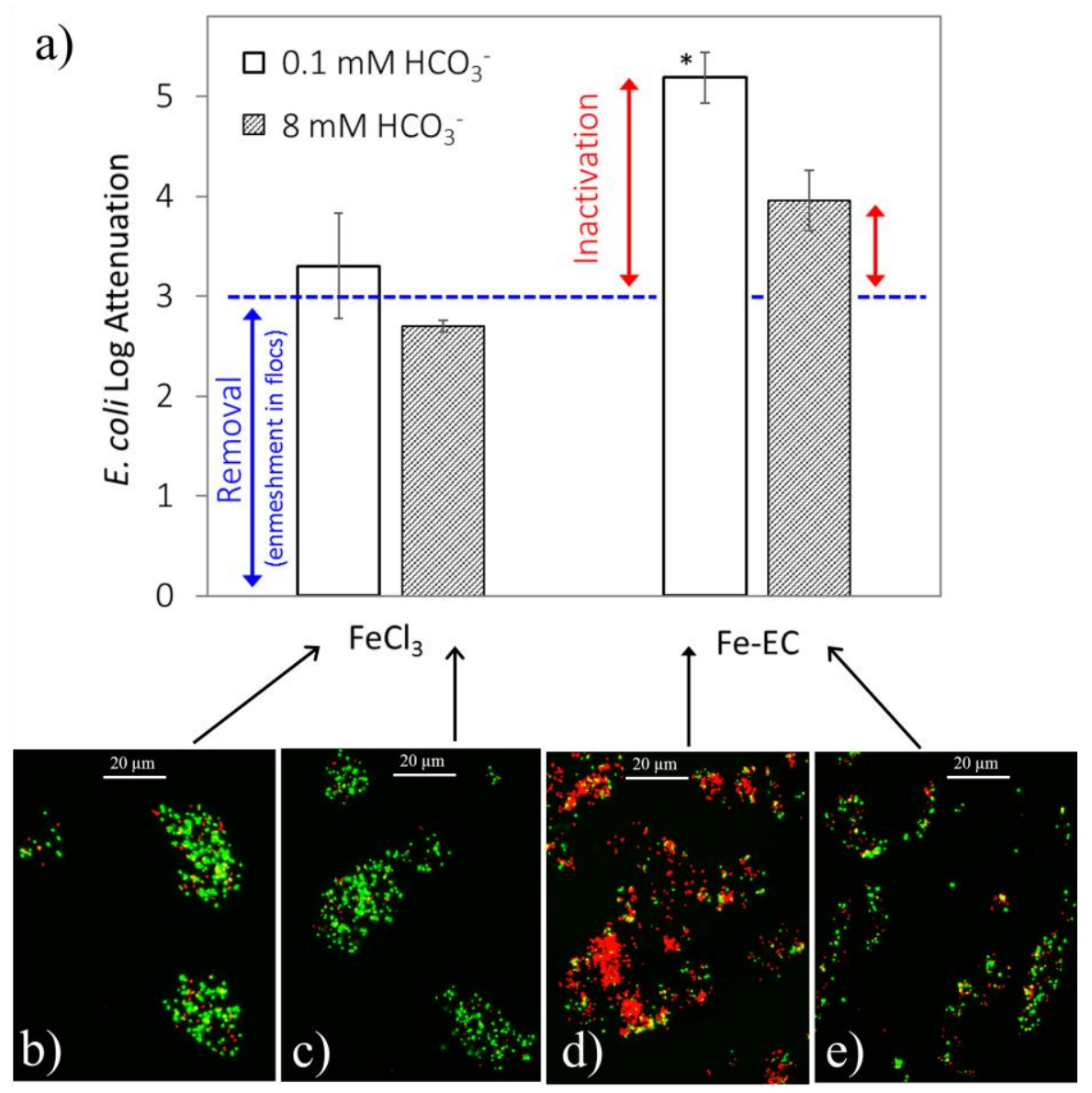

Figure 1: $E$. coli attenuation with $\mathrm{Fe}-\mathrm{EC}$ and $\mathrm{FeCl}_{3}$, with and without $8 \mathrm{mM} \mathrm{HCO}_{3}^{-}$. Fe dosage was $0.5 \mathrm{mM}$ in all experiments. Panel a shows E. coli log attenuations. The asterisk indicates that the detection limit for bacteria attenuation was reached for some of the replicate experiments. Panels b-e show fluorescent microscopy images of live (green)-dead (red) stained E. coli cells. The blue dashed line is the average attenuation in all $\mathrm{FeCl}_{3}$ experiments (with and without $\mathrm{HCO}_{3}{ }^{-}$) and represents removal (blue arrow). E. coli log attenuations are compared to this baseline to deduce approximate log inactivations (red arrows). All experiments were conducted at $\mathrm{pH}$ 7.0. In $0.1 \mathrm{mM} \mathrm{HCO}_{3}{ }^{-}$experiments, $2 \mathrm{mM} \mathrm{NaCl}$ were added for conductivity. 


\section{Single solute electrolytes (no oxyanions, no $\mathrm{HCO}_{3}{ }^{-}$)}

a)

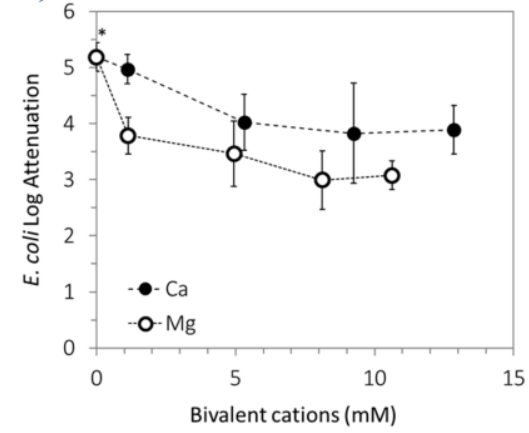

b)

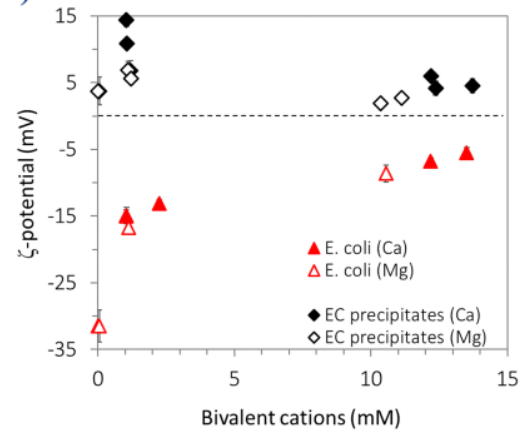

c)

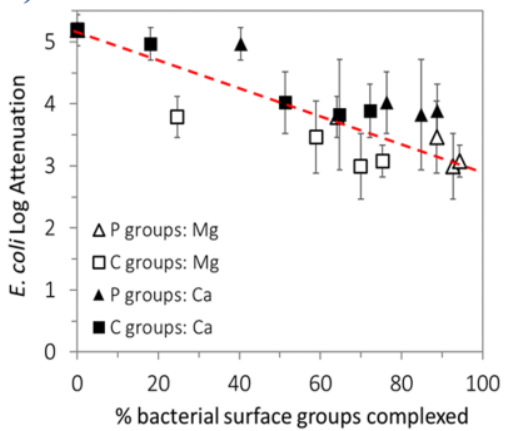

Groundwater-like electrolytes ( $\left.8 \mathrm{mM} \mathrm{HCO}_{3}{ }^{-}, 1.2 \mathrm{mM} \mathrm{Si}, 0.4 \mathrm{mM} \mathrm{P}\right)$

d)

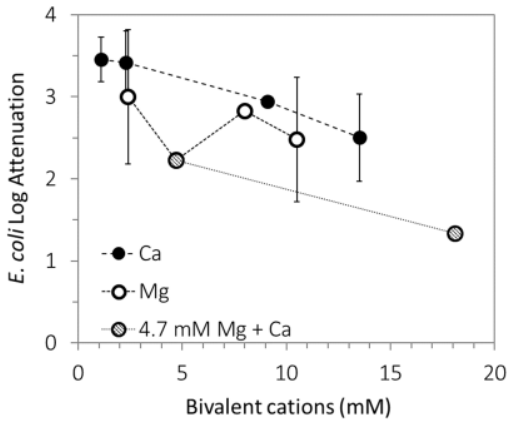

e)

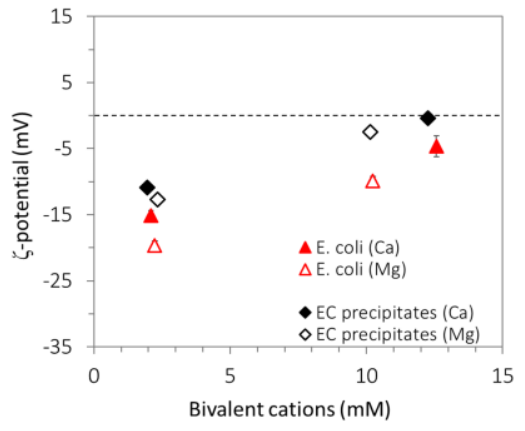

f)

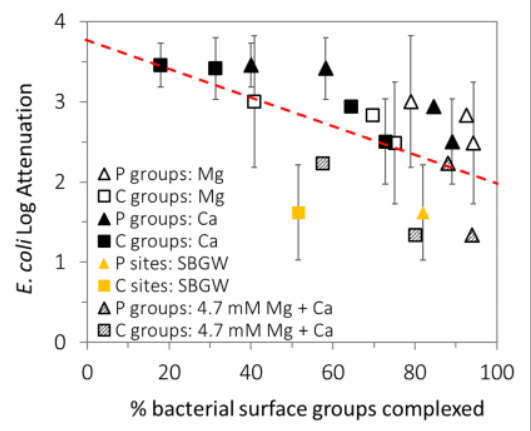

Figure 2: Effect of Ca and Mg on $\boldsymbol{E}$. coli attenuation in Fe-EC, in single solute electrolytes (panels a, b and c) and in groundwater-like electrolytes containing $8 \mathrm{mM} \mathrm{HCO}_{3}{ }^{-}, 1.2 \mathrm{mM} \mathrm{Si}$, and $0.4 \mathrm{mM} \mathrm{P}$ (panels d, $\mathrm{e}$ and $\mathrm{f}$ ). Panels a and d: effect of increasing $\mathrm{Ca} / \mathrm{Mg}$ concentrations on $E$. coli log attenuation with an $\mathrm{Fe}$ dosage of $0.5 \mathrm{mM}$. The asterisk indicates that the detection limit for bacteria attenuation was reached for some of the replicate experiments. Panels $\mathrm{b}$ and e: effect of increasing $\mathrm{Ca} / \mathrm{Mg}$ concentrations on the $\zeta$ potential of EC precipitates and E. coli cells (data points for $0 \mathrm{mM} \mathrm{Ca}$ and $0 \mathrm{mM} \mathrm{Mg}$ overlap on panel b). Panels c and f: E. coli attenuation as a function of complexed bacterial surface groups (combination of Figures $2 \mathrm{a}$ and $\mathrm{S} 3$, and $2 \mathrm{~d}$ and $\mathrm{S} 3$, respectively). The dotted red lines highlight the inverse correlation between $E$. coli attenuation and the complexation of bacterial functional groups. All experiments were conducted at $\mathrm{pH}$ 7.0. Experiments with no $\mathrm{Ca} / \mathrm{Mg}$ (panel a) were conducted in $2 \mathrm{mM} \mathrm{NaCl}$ for conductivity. 
Simple electrolytes ( $2 \mathrm{mM} \mathrm{NaCl}$, no bivalent cations, no $\mathrm{HCO}_{3}{ }^{-}$)

a)

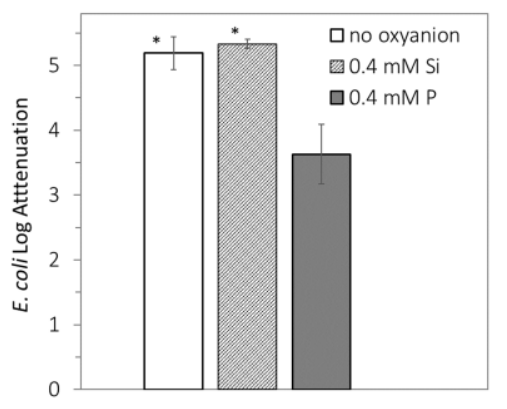

b)

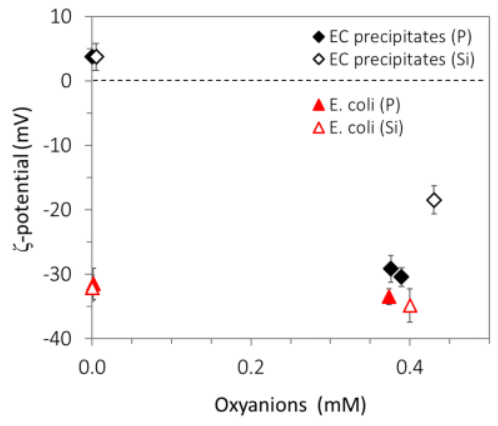

c)

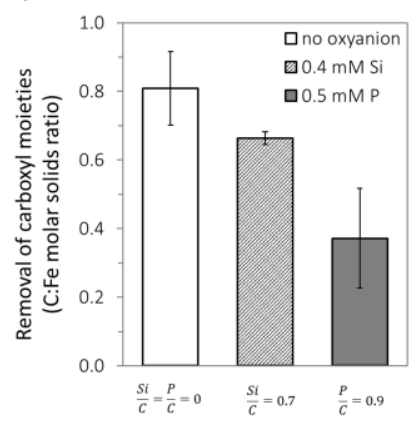

Groundwater-like electrolytes (bivalent cations, $8 \mathrm{mM} \mathrm{HCO}_{3}^{-}, 1.2 \mathrm{mM} \mathrm{Si}$ )

d)

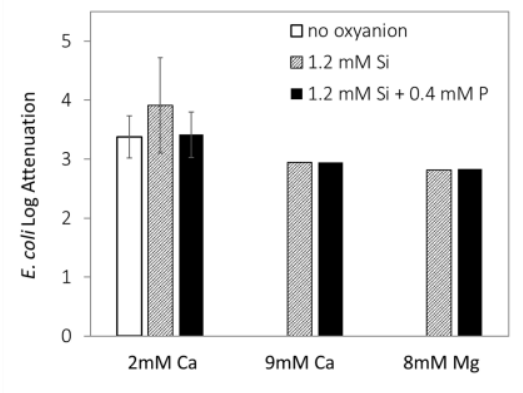

e)

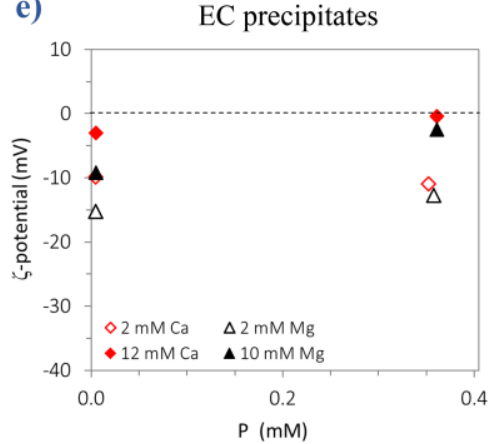

f)

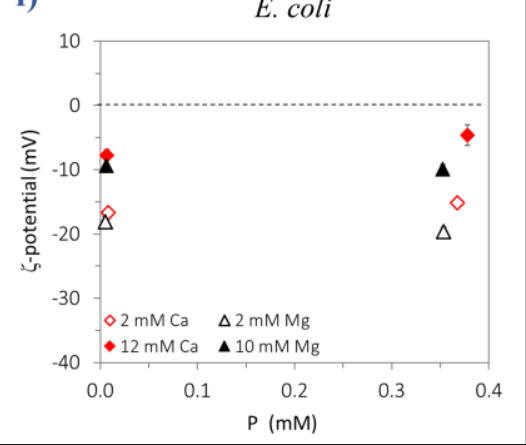

Figure 3: Effect of $P$ and Si on $\boldsymbol{E}$. coli attenuation by Fe-EC with an Fe dosage of $0.5 \mathrm{mM}$ in single solute electrolytes $(0.4 \mathrm{mM} \mathrm{P}$ or $\mathrm{Si}$ in $2 \mathrm{mM} \mathrm{NaCl}$ background for conductivity; panels a,b and c) and groundwater-like electrolytes containing $8 \mathrm{mM} \mathrm{HCO}_{3}^{-}, 1.2 \mathrm{mM} \mathrm{Si}$, and bivalent cations (panels, $\mathrm{d}$, e and f). a) Effect of Si and $\mathrm{P}$ on $E$. coli attenuation. Asterisks indicate that the detection limit for bacteria attenuation was reached for some of the replicate experiments. b) Effect of Si (open symbols) and P (solid symbols) on the $\zeta$-potential of EC precipitates and $E$. coli cells. c) Effect of $\mathrm{P}$ and Si on the removal of citrate (a proxy for carboxyl moieties) by Fe-EC. d) Effect of $\mathrm{P}$ on $E$. coli attenuation at different levels of $\mathrm{Ca} / \mathrm{Mg}$. e) Effect of $\mathrm{P}$ on the $\zeta$-potential of EC precipitates. f) Effect of $\mathrm{P}$ on the $\zeta$-potential of $E$. coli cells. All experiments were conducted at $\mathrm{pH} 7.0$. 


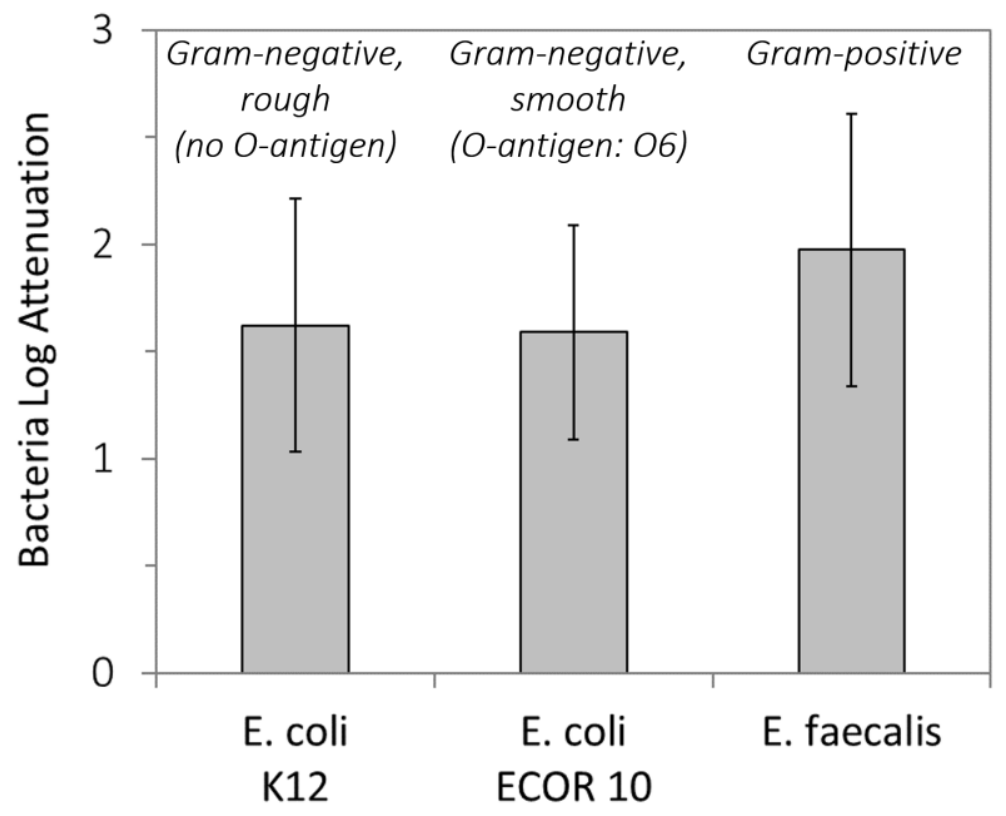

Figure 4: Log attenuation of three different bacterial strains by Fe-EC, at an Fe dosage of $0.5 \mathrm{mM}$. All experiments were conducted at $\mathrm{pH} 7.5$ in $\mathrm{SBGW}\left(8.2 \mathrm{mM} \mathrm{HCO}_{3}^{-}, 2.7 \mathrm{mM} \mathrm{Ca}, 2.0 \mathrm{mM} \mathrm{Mg}, 1.3 \mathrm{mM}\right.$ $\mathrm{Si}, 0.15 \mathrm{mM}$ P, and $6.3 \mu \mathrm{M}$ As(III)). The log attenuation of E. coli $\mathrm{K} 12$ in SBGW shown here has also been reported elsewhere (Delaire et al., 2015). 
Alt, E., Leipold, F., Milatovic, D., Lehmann, G., Heinz, S., Schömig, A., 1999. Hydrogen peroxide for prevention of bacterial growth on polymer biomaterials. Ann. Thorac. Surg. 68, 2123-2128. doi:10.1016/S0003-4975(99)00832-2

Amrose, S.E., Bandaru, S.R.S., Delaire, C., van Genuchten, C.M., Dutta, A., DebSarkar, A., Orr, C., Roy, J., Das, A., Gadgil, A.J., 2014. Electro-chemical arsenic remediation: field trials in West Bengal. Sci. Total Environ. 488-489, 539-46. doi:10.1016/j.scitotenv.2013.11.074

Appenzeller, B.M.R., Duval, Y.B., Thomas, F., Block, J.-C., 2002. Influence of Phosphate on Bacterial Adhesion onto Iron Oxyhydroxide in Drinking Water. Environ. Sci. Technol. 36, 646-652. doi:10.1021/es010155m

Arai, Y., Sparks, D.L., 2001. ATR-FTIR Spectroscopic Investigation on Phosphate Adsorption Mechanisms at the FerrihydriteWater Interface. J. Colloid Interface Sci. 241, 317-326. doi:10.1006/jcis.2001.7773

Augusto, O., Miyamoto, S., 2011. Oxygen Radicals and Related Species | Ohara Augusto - Academia.edu, in: Pantopoulos, H.M. (Ed.), Principles of Free Radical Biomedicine. Volume 1. Nova Science Publishers, Inc.

Barrera-Díaz, C., Ureña-Nuñez, F., Campos, E., Palomar-Pardavé, M., Romero-Romo, M., 2003. A combined electrochemicalirradiation treatment of highly colored and polluted industrial wastewater. Radiat. Phys. Chem. 67, 657-663. doi:10.1016/S0969-806X(02)00497-8

Beveridge, T.J., Koval, S.F., 1981. Binding of metals to cell envelopes of Escherichia coli K-12. Appl. Environ. Microbiol. 42 , $325-35$.

Borrok, D., Turner, B.F., Fein, J.B., 2005. A universal surface complexation framework for modeling proton binding onto bacterial surfaces in geologic settings. Am. J. Sci. 305, 826-853. doi:10.2475/ajs.305.6-8.826

Chan, C.S., Fakra, S.C., Edwards, D.C., Emerson, D., Banfield, J.F., 2009. Iron oxyhydroxide mineralization on microbial extracellular polysaccharides. Geochim. Cosmochim. Acta 73, 3807-3818.

Chassé, A.W., Ohno, T., Higgins, S.R., Amirbahman, A., Yildirim, N., Parr, T.B., 2015. Chemical Force Spectroscopy Evidence Supporting the Layer-by-Layer Model of Organic Matter Binding to Iron (oxy)Hydroxide Mineral Surfaces. Environ. Sci. Technol. 49, 9733-41. doi:10.1021/acs.est.5b01877

Chen, G., Walker, S.L., 2012. Fecal indicator bacteria transport and deposition in saturated and unsaturated porous media. Environ. Sci. Technol. 46, 8782-90. doi:10.1021/es301378q

Chen, J., Gu, B., Leboeuf, E.J., Pan, H., Dai, S., 2002. Spectroscopic characterization of the structural and functional properties of natural organic matter fractions. Chemosphere 48, 59-68.

Delaire, C., van Genuchten, C.M., Nelson, K.L., Amrose, S.E., Gadgil, A.J., 2015. Escherichia coli Attenuation by Fe Electrocoagulation in Synthetic Bengal Groundwater: Effect of $\mathrm{pH}$ and Natural Organic Matter. Environ. Sci. Technol. 49, 9945-53. doi:10.1021/acs.est.5b01696

Driver, S.J., Perdue, E.M., 2014. Advances in the Physicochemical Characterization of Dissolved Organic Matter: Impact on Natural and Engineered Systems, ACS Symposium Series. American Chemical Society, Washington, DC. doi:10.1021/bk2014-1160

Elzinga, E.J., Huang, J.-H., Chorover, J., Kretzschmar, R., 2012. ATR-FTIR spectroscopy study of the influence of pH and contact time on the adhesion of Shewanella putrefaciens bacterial cells to the surface of hematite. Environ. Sci. Technol. 46, 12848-55. doi:10.1021/es303318y

Felix, A., Pitt, R.M., 1935. Virulence and Immunogenic Activities of B. typhosus in Relation to its Antigenic Constituents. J. Hyg. (Lond). 35, 428-36.

Filius, J.D., Lumsdon, D.G., Meeussen, J.C.L., Hiemstra, T., Van Riemsdijk, W.H., 2000. Adsorption of fulvic acid on goethite. Geochim. Cosmochim. Acta 64, 51-60. doi:10.1016/S0016-7037(99)00176-3

Ghernaout, D., Badis, A., Kellil, A., Ghernaout, B., 2008. Application of electrocoagulation in Escherichia coli culture and two surface waters. Desalination 219, 118-125. doi:10.1016/j.desal.2007.05.010

Hamid, R.D., Swedlund, P.J., Song, Y., Miskelly, G.M., 2011. Ionic strength effects on silicic acid (H4SiO4) sorption and oligomerization on an iron oxide surface: an interesting interplay between electrostatic and chemical forces. Langmuir 27, 12930-7. doi:10.1021/la201775c

Holt, P.K., Barton, G.W., Mitchell, C.A., 2005. The future for electrocoagulation as a localised water treatment technology. Chemosphere 59, 355-67. doi:10.1016/j.chemosphere.2004.10.023

Hug, S.J., Leupin, O., 2003. Iron-catalyzed oxidation of arsenic(III) by oxygen and by hydrogen peroxide: pH-dependent formation of oxidants in the Fenton reaction. Environ. Sci. Technol. 37, 2734-42. 
Ikawa, S., Kitano, K., Hamaguchi, S., 2010. Effects of pH on Bacterial Inactivation in Aqueous Solutions due to LowTemperature Atmospheric Pressure Plasma Application. Plasma Process. Polym. 7, 33-42. doi:10.1002/ppap.200900090

Jacobsen, F., Holcman, J., Sehested, K., 1998. Reactions of the ferryl ion with some compounds found in cloud water. Int. J. Chem. Kinet. 30, 215-221. doi:10.1002/(SICI)1097-4601(1998)30:3<215::AID-KIN7>3.0.CO;2-V

Jacobson, K.H., Gunsolus, I.L., Kuech, T.R., Troiano, J.M., Melby, E.S., Lohse, S.E., Hu, D., Chrisler, W.B., Murphy, C.J., Orr, G., Geiger, F.M., Haynes, C.L., Pedersen, J.A., 2015. Lipopolysaccharide Density and Structure Govern the Extent and Distance of Nanoparticle Interaction with Actual and Model Bacterial Outer Membranes. Environ. Sci. Technol. 49, 10642-10650. doi:10.1021/acs.est.5b01841

Johnson, K.J., Szymanowski, J.E.S., Borrok, D., Huynh, T.Q., Fein, J.B., 2007. Proton and metal adsorption onto bacterial consortia: Stability constants for metal-bacterial surface complexes. Chem. Geol. 239, 13-26.

Kanematsu, M., Young, T.M., Fukushi, K., Green, P.G., Darby, J.L., 2013. Arsenic(III, V) adsorption on a goethite-based adsorbent in the presence of major co-existing ions: Modeling competitive adsorption consistent with spectroscopic and molecular evidence. Geochim. Cosmochim. Acta 106, 404-428. doi:10.1016/j.gca.2012.09.055

Keenan, C.R., Sedlak, D.L., 2008. Factors Affecting the Yield of Oxidants from the Reaction of Nanoparticulate Zero-Valent Iron and Oxygen. Environ. Sci. Technol. 42, 1262-1267. doi:10.1021/es7025664

Kelly, S.D., Hesterberg, D., Ravel, B., 2008. Analysis of soils and minerals using X-ray absorption spectroscopy, in: Methods of Soil Analysis. Part 5. Mineralogical Methods.

Kim, J.Y., Park, H.-J., Lee, C., Nelson, K.L., Sedlak, D.L., Yoon, J., 2010. Inactivation of Escherichia coli by nanoparticulate zerovalent iron and ferrous ion. Appl. Environ. Microbiol. 76, 7668-70. doi:10.1128/AEM.01009-10

Li, L., Li, J., Shao, C., Zhang, K., Yu, S., Gao, N., Deng, Y., Yin, D., 2014. Arsenic removal in synthetic ground water using iron electrolysis. Sep. Purif. Technol. 122, 225-230. doi:10.1016/j.seppur.2013.11.012

Li, L., van Genuchten, C.M., Addy, S.E.A., Yao, J., Gao, N., Gadgil, A.J., 2012. Modeling As(III) oxidation and removal with iron electrocoagulation in groundwater. Environ. Sci. Technol. 46, 12038-45. doi:10.1021/es302456b

Madigan, M.T., Martinko, J.M., Parker, J., 2000. Brock biology of microorganisms. Prentice Hall, Upper Saddle River NJ.

Mazel, D., Dychinco, B., Webb, V.A., Davies, J., 2000. Antibiotic resistance in the ECOR collection: integrons and identification of a novel aad gene. Antimicrob. Agents Chemother. 44, 1568-74.

McBride, M.B., Kung, K.-H., 1991. Adsorption of phenol and substituted phenols by iron oxides. Environ. Toxicol. Chem. 10, 441-448. doi:10.1002/etc.5620100403

Medinas, D.B., Cerchiaro, G., Trindade, D.F., Augusto, O., 2007. The carbonate radical and related oxidants derived from bicarbonate buffer. IUBMB Life 59, 255-62. doi:10.1080/15216540701230511

Miot, J., Benzerara, K., Obst, M., Kappler, A., Hegler, F., Schädler, S., Bouchez, C., Guyot, F., Morin, G., 2009. Extracellular iron biomineralization by photoautotrophic iron-oxidizing bacteria. Appl. Environ. Microbiol. 75, 5586-91. doi:10.1128/AEM.00490-09

Mohanty, S.K., Torkelson, A.A., Dodd, H., Nelson, K.L., Boehm, A.B., 2013. Engineering solutions to improve the removal of fecal indicator bacteria by bioinfiltration systems during intermittent flow of stormwater. Environ. Sci. Technol. 47, 10791-8. doi:10.1021/es305136b

Neta, P., Huie, R.E., Ross, A.B., 1988. Rate Constants for Reactions of Inorganic Radicals in Aqueous Solution. J. Phys. Chem. Ref. Data 17, 1027. doi:10.1063/1.555808

Ngwenya, B.T., Sutherland, I.W., Kennedy, L., 2003. Comparison of the acid-base behaviour and metal adsorption characteristics of a gram-negative bacterium with other strains. Appl. Geochemistry 18, 527-538.

Norén, K., Loring, J.S., Persson, P., 2008. Adsorption of alpha amino acids at the water/goethite interface. J. Colloid Interface Sci. 319, 416-28. doi:10.1016/j.jcis.2007.11.046

Omoike, A., Chorover, J., Kwon, K.D., Kubicki, J.D., 2004. Adhesion of bacterial exopolymers to alpha-FeOOH: inner-sphere complexation of phosphodiester groups. Langmuir 20, 11108-14. doi:10.1021/la048597+

Parikh, S.J., Chorover, J., 2006. ATR-FTIR spectroscopy reveals bond formation during bacterial adhesion to iron oxide. Langmuir 22, 8492-500. doi:10.1021/la061359p

Parikh, S.J., Mukome, F.N.D., Zhang, X., 2014. ATR-FTIR spectroscopic evidence for biomolecular phosphorus and carboxyl groups facilitating bacterial adhesion to iron oxides. Colloids Surf. B. Biointerfaces 119, 38-46. 
doi:10.1016/j.colsurfb.2014.04.022

Roberts, L.C., Hug, S.J., Ruettimann, T., Billah, M.M., Khan, A.W., Rahman, M.T., 2004. Arsenic Removal with Iron(II) and Iron(III) in Waters with High Silicate and Phosphate Concentrations. Environ. Sci. Technol. 38, 307-315. doi:10.1021/es0343205

Senn, A.-C., Kaegi, R., Hug, S.J., Hering, J.G., Mangold, S., Voegelin, A., 2015. Composition and structure of Fe(III)precipitates formed by $\mathrm{Fe}(\mathrm{II})$ oxidation in water at near-neutral $\mathrm{pH}$ : Interdependent effects of phosphate, silicate and $\mathrm{Ca}$. Geochim. Cosmochim. Acta 162, 220-246. doi:10.1016/j.gca.2015.04.032

Sposito, G., 2008. The Chemistry of Soils. Oxford University Press.

Stachowicz, M., Hiemstra, T., van Riemsdijk, W.H., 2008. Multi-competitive interaction of As(III) and As(V) oxyanions with $\mathrm{Ca}(2+), \mathrm{Mg}(2+), \mathrm{PO}(3-)(4)$, and $\mathrm{CO}(2-)(3)$ ions on goethite. J. Colloid Interface Sci. 320, 400-14. doi:10.1016/j.jcis.2008.01.007

STEC center, 2016. STEC center website [WWW Document]. URL http://shigatox.net/new/reference-strains/ecor.html (accessed 1.1.16).

Stevenson, G., Neal, B., Liu, D., Hobbs, M., Packer, N.H., Batley, M., Redmond, J.W., Lindquist, L., Reeves, P., 1994. Structure of the $\mathrm{O}$ antigen of Escherichia coli K-12 and the sequence of its rfb gene cluster. J. Bacteriol. 176, 4144-56.

Tanneru, C.T., Chellam, S., 2012. Mechanisms of virus control during iron electrocoagulation--microfiltration of surface water. Water Res. 46, 2111-20. doi:10.1016/j.watres.2012.01.032

Truesdail, S.., Lukasik, J., Farrah, S.., Shah, D.., Dickinson, R.., 1998. Analysis of Bacterial Deposition on Metal (Hydr)oxideCoated Sand Filter Media. J. Colloid Interface Sci. 203, 369-378. doi:10.1006/jcis.1998.5541

van Genuchten, C.M., Addy, S.E.A., Peña, J., Gadgil, A.J., 2012. Removing arsenic from synthetic groundwater with iron electrocoagulation: an Fe and As K-edge EXAFS study. Environ. Sci. Technol. 46, 986-94. doi:10.1021/es201913a

van Genuchten, C.M., Gadgil, A.J., Peña, J., 2014a. Fe(III) nucleation in the presence of bivalent cations and oxyanions leads to subnanoscale 7 Å polymers. Environ. Sci. Technol. 48, 11828-36. doi:10.1021/es503281a

van Genuchten, C.M., Peña, J., Amrose, S.E., Gadgil, A.J., 2014b. Structure of Fe(III) precipitates generated by the electrolytic dissolution of $\mathrm{Fe}(0)$ in the presence of groundwater ions. Geochim. Cosmochim. Acta 127, 285-304. doi:10.1016/j.gca.2013.11.044

Voegelin, A., Kaegi, R., Frommer, J., Vantelon, D., Hug, S.J., 2010. Effect of phosphate, silicate, and Ca on Fe(III)-precipitates formed in aerated $\mathrm{Fe}(\mathrm{II})$ - and $\mathrm{As}(\mathrm{III})$-containing water studied by X-ray absorption spectroscopy. Geochim. Cosmochim. Acta 74, 164-186. doi:10.1016/j.gca.2009.09.020

Walker, S.L., Redman, J.A., Elimelech, M., 2004. Role of Cell Surface Lipopolysaccharides in Escherichia coli K12 adhesion and transport. Langmuir 20, 7736-46. doi:10.1021/la049511f

WHO, 2011. WHO | Guidelines for drinking-water quality, fourth edition. World Health Organization.

Yan, W., Wang, H., Jing, C., 2016. Adhesion of Shewanella oneidensis MR-1 to Goethite: A Two-Dimensional Correlation Spectroscopic Study. Environ. Sci. Technol. 50, 4343-9. doi:10.1021/acs.est.6b00066 